\title{
PEMANFAATAN LIMBAH IKAN SIDAT INDONESIA (Anguilla bicolor) SEBAGAI TEPUNG PADA INDUSTRI PENGOLAHAN IKAN DI PALABUHANRATU, KABUPATEN SUKABUMI
}

\author{
(Utilization of Indonesian Eel [Anguilla bicolor] by product as Flour at The Fishery Processing \\ Industry in Palabuhanratu, Sukabumi District)
}

RA Hangesti Emi Widyasari ${ }^{1 *}$, Clara M Kusharto², Budy Wiryawan¹, Eko Sri Wiyono ${ }^{1}$, dan Sugeng Heri Suseno ${ }^{3}$

'Departemen Pemanfaatan Sumberdaya Perikanan, Fakultas Perikanan dan Ilmu Kelautan (FPIK), Institut Pertanian Bogor, Bogor 16680

2Departemen Gizi Masyarakat, Fakultas Ekologi Manusia (FEMA), Institut Pertanian Bogor, Bogor 16680

${ }^{3}$ Departemen Teknologi Hasil Perairan, Fakultas Perikanan dan Ilmu Kelautan (FPIK), Institut Pertanian Bogor, Bogor 16680

\begin{abstract}
This research aims to analyze the nutritive value of flour head, liver powder and bone meal as by product of Indonesian eel (Anguilla bicolor) processing. Eel waste flour was made by using a thermal process in the drum dryer fish flouring mill PT. Carmelitha Lestari in Bogor, whereas proximate analysis for chemical tests were performed in the laboratory of Integrated Chemical Laboratory, IPB and direct observation was conducted in PT Jawa Suisan Indah, Palabuhanratu Sukabumi district in October 2012-April 2013. The nutritive value based on proximate analysis showed that head flour, liver flour, and bone flour contained protein 61.78\%, $53.92 \%$, and $41.01 \%$; fat $15.55 \%, 27.28 \%$, $13.07 \%$; carbohydrate $11.48 \%$; $14.96 \%$, $8.13 \%$; water $5.44 \%, 8.48 \%$, $3.01 \%$; ash $12.95 \%, 3.62 \%, 37.49 \%$, and crude fiber $1.33 \%, 0.04 \%, 1.11 \%$, respectively.
\end{abstract}

Keywords: Anguilla bicolor, bone flour, head flour, liver flour, nutritive value

\begin{abstract}
ABSTRAK
Penelitian ini bertujuan untuk menganalisis kandungan gizi tepung kepala, tepung tulang dan tepung hati ikan yang merupakan limbah pengolahan ikan sidat Indonesia (Anguilla bicolor). Tepung limbah ikan sidat dibuat berdasarkan proses termal menggunakan drum dryer di pabrik penepungan ikan PT. Carmelitha Lestari di Bogor dan analisis proksimat untuk uji kimiawi dilakukan di Laboratorium Kimia Terpadu, IPB serta observasi langsung di PT Jawa Suisan Indah, Palabuhanratu Kabupaten Sukabumi pada bulan Oktober 2012-April 2013. Hasil analisis proksimat tepung kepala, tepung hati dan tepung tulang mengandung protein berturut-turut sebesar 61.78\%, 53.92\%, dan 41.01\%; lemak sebesar 15.55\%; 27.28\%; 13.07\%, karbohidrat sebesar 11.48\%; $14.96 \%$; 8.13\%, kadar air sebesar 5.44\%; 8.48\%; 3.01\%, kadar abu $12.95 \%$; 3.62\%; 37.49\% dan serat kasar $1.33 \%$; $0.04 \% ; 1.11 \%$.
\end{abstract}

Kata kunci: Anguilla bicolor, nilai gizi, tepung hati, tepung kepala, tepung tulang

"Korespondensi: Departemen Pemanfaatan Sumberdaya Perikanan, Fakultas Perikanan dan Ilmu Kelautan (FPIK), Institut Pertanian Bogor, Bogor 16680. Email: hangesti_widyasari@yahoo.com 


\section{PENDAHULUAN}

Perikanan adalah salah satu sektor yang diandalkan untuk pembangunan masa depan Indonesia karena memiliki potensi untuk berkontribusi dalam pemenuhan gizi masyarakat Indonesia. Produk hasil perikanan pada umumnya mengandung protein yang tinggi dan merupakan bahan makanan yang umum dikonsumsi masyarakat (KKP 2011). Ikan sidat (Anguilla sp.) merupakan salah satu produk perikanan yang memiliki nilai jual yang tinggi dan telah dibudidayakan melalui sistem intensif atau ekstensif terutama di Asia (Altun et al. 2005; Heinsbroek 1991). Tahun 2010, produksi ikan sidat dunia diperkirakan mencapai 8440 ton senilai 36 juta US\$ (FAO 2010). Setiap tahunnya Negara Cina membutuhkan pasokan ikan sidat untuk bahan baku olahan tak kurang dari 70000 ton, sementara saat ini mereka baru bisa memenuhi sekitar 20000 ton saja. Selain itu kebutuhan konsumen Jepang akan ikan sidat mencapai 300000 ton/tahun, Korea 15000 ton/tahun dan Taiwan 5000 ton/tahun (KKP 2011). Ikan sidat yang dijual dalam keadaan hidup, segar, beku, dan olahan memiliki nilai jual yang berbeda. Salah satu contoh olahan ikan sidat yang bernilai ekonomi tinggi adalah sidat panggang (Kabayaki).

Kini Indonesia menjadi salah satu negara tujuan untuk mendapatkan ikan sidat hidup dan olahan (KKP 2011). Seiring dengan tingginya permintaan ikan sidat olahan kabayaki, jumlah limbah yang dihasilkan juga meningkat, karena itu perlu dilakukan penerapan teknologi pasca panen yang efisien dan optimal serta upaya-upaya yang tepat pada industri pengolahan perikanan sidat. Jika memungkinkan hingga zero waste dapat memberikan nilai tambah kepada masyarakat nelayan. Salah satu cara yang dapat dilakukan untuk memanfaatkan limbah tersebut dengan cara mengolahnya menjadi tepung ikan.

Penelitian ini bertujuan untuk menganalisis kandungan gizi tepung kepala, tepung tulang, dan tepung hati yang merupakan limbah pengolahan ikan sidat Indonesia (Anguilla bicolor).

\section{METODE}

\section{Tempat, Waktu, dan Bahan Penelitian}

Penelitian dilakukan di PT. Carmelitha Lestari di Bogor dan analisis kimia tepung ikan bertempat di Laboratorium Kimia Terpadu, Institut Pertanian Bogor. Penelitian ini dilaksanakan bulan Oktober 2012-April 2013 yang merupakan bagian dari penelitian disertasi "Model Keberlanjutan Integrasi Industri Perikanan Sidat di Palabuhanratu, Kabupaten Sukabumi”.

Bahan yang digunakan dalam pembuatan tepung ikan sidat adalah ikan sidat (Anguilla bicol- or) segar bagian kepala, tulang dan hati serta air. Ikan sidat diperoleh dari unit pengolahan sidat panggang beku PT. Jawa Suisan Indah, di Stasiun Lapang Kelautan Fakultas Perikanan dan Ilmu Kelautan IPB Palabuhanratu, Kabupaten Sukabumi. Alat-alat yang digunakan dalam pembuatan tepung ikan adalah ember, autoklaf, kain kasa, hydrolic press, drum dryer dan mesin penggiling (willey mill). Bahan-bahan yang digunakan untuk analisis kimia diantaranya akuades, selenium, $\mathrm{n}$-hexane, $\mathrm{HCl}$, Selenium-mix, $\mathrm{H}_{2} \mathrm{SO}_{4}$ pekat, $\mathrm{H}_{2} \mathrm{SO}_{4} 1.25 \%, \mathrm{NaOH} 40 \%, \mathrm{NaOH} 3.25 \%$, asam borat, indikator (merah metil dan metil biru), $\mathrm{HCl} 0.1 \mathrm{~N}$, dan etanol. Alat-alat yang digunakan dalam analisis kimia adalah oven vakum, cawan alumunium, cawan porselin, tanur, pengaduk magnetik, sentrifus, gelas ukur labu kjedahl, alat ekstraksi soxhlet, desikator, kertas saring, timbangan, labu lemak, pembakar bunsen, alat destilasi, labu erlenmeyer dan beacker gelas.

\section{Tahapan Penelitian}

Pembuatan tepung kepala ikan sidat, tepung tulang dan tepung hati ikan sidat adalah sebagai berikut; pada bak penampungan ikan sidat hidup yang sudah dipingsankan pada suhu dingin $0-5^{\circ} \mathrm{C}$, dipotong kepalanya dan dipisahkan fillet dagingnya untuk dibuat ikan sidat panggang. Kepala, tulang, dan hati ikan sidat di unit pengolahan sidat disisihkan dan masing-masing dibersihkan secara terpisah, kemudian ditiriskan dan dikemas dalam kantong plastik untuk dibekukan pada mesin pembeku. Kepala, tulang, dan hati ikan sidat masing-masing dibawa ke pabrik penepungan di Bogor dengan menggunakan metode yang mengacu pada Mervina et al. (2012). Limbah ikan sidat segera dicuci bersih masing-masing secara terpisah dan dimasak dengan tekanan tinggi (presto) dan suhu $121^{\circ} \mathrm{C}$ selama 2 jam. Proses selanjutnya, kepala, tulang dan hati ikan yang telah matang masing-masing dibungkus dengan kain kasa dan dipres dengan hydrolic press. Ikan yang telah agak kering kemudian dikeringkan dengan drum dryer pada suhu $80^{\circ} \mathrm{C}$ dengan tekanan 3 bar. Lalu serpihan ikan yang telah kering digiling dengan willey mill sehingga menghasilkan tepung kepala, tepung tulang, dan tepung hati ikan sidat.

Kebutuhan data dan informasi untuk penelitian ini diperoleh melalui pengamatan langsung di PT. Jawa Suisan Indah, wawancara dengan ahli kabayaki dari Jepang dan para teknisi untuk mengetahui penanganan limbah ikan sidat hingga unit pengolahan tepung ikan di PT. Carmelitha Lestari. Tepung kepala, tulang, dan hati ikan sidat dianalisis sifat kimianya mengacu pada AOAC (1995) meliputi kadar air, abu, lemak, protein, dan karbohidrat serta serat kasar yang dilakukan di Laboratorium Terpadu IPB. Selain itu dilakukan juga analisis kimia terhadap 
ikan sidat segar dan kabayaki sebagai pembanding menggunakan metode yang sama.

\section{HASIL DAN PEMBAHASAN}

Perusahaan industri perikanan sidat di $\mathrm{Pa}$ labuhanratu bergerak di bidang penangkapan dan budidaya serta pengolahan sidat panggang (kabayaki) secara semi modern. Limbah yang dihasilkan pada unit pengolahan kabayaki seperti kepala, tulang, isi perut masih menjadi masalah dan terbuang percuma sehingga menimbulkan masalah lingkungan bagi unit pengolahan tersebut. Menurut Mr. Hisayasu Ishitani, pemilik PT. Jawa Suisan Indah, di Jepang biasanya bagian isi perut (hati, jantung, dan lambung) digunakan untuk sup dengan nama kimo soup atau bisa juga dengan dibakar saja. Selain itu bagian kepala dapat dipanggang atau diolah menjadi sup kepala ikan. Penelitian yang dilakukan Harris et al. (2012) menunjukkan bahwa pengolahan limbah produk berbasis ikan menjadi tepung ikan memiliki peluang bisnis yang prospektif. Berdasarkan hal tersebut, penelitian ini berupaya untuk memanfaatkan limbah olahan kabayaki dengan cara mengolahnya menjadi tepung.

Tepung ikan mengandung nilai gizi yang tinggi terutama kandungan protein yang kaya akan asam amino esensial yaitu lisin dan metionin. Produksi pembuatan tepung ikan dalam jumlah yang besar menurut FAO PBB yaitu hampir 90\% digunakan sebagai konsumsi makanan manusia (Green 2010). Beberapa penelitian menunjukkan bahwa tepung ikan selain digunakan sebagai pakan (Cameron 1960; Wu et al. 1999; Kureshy et al. 2000, Traylor et al. 2005; Mercy et al. 2006; Gimenez et al. 2009; Hadi et al. 2009); Indarti et al. 2012; Sari et al. 2012; Napitu et al. 2013; Selpiana et al. 2013; Yolanda et al. 2013) dapat digunakan pula sebagai bahan substitusi makanan seperti produk susu (Huber \& Slade 1967), biskuit (Talib et al. 2007; Salamah \& Santoso 2008; Mervina et al. 2012), crackers (Maulida 2005; Ferazuma et al. 2011), roti (Adeleke \& Odedeji 2010), mie instan (Haryati et al. 2006), dan suplemen makanan (Shurpalekar et al. 1963; Pretorius \& Wehmeyer 1964).

Menurut Clusac dan Ward (1996) pengolahan ikan segar menjadi tepung ikan dapat dilakukan melalui dua cara yaitu cara kering (dry process) dan cara basah (wet process). Cara kering dilakukan pada ikan berkadar lemak rendah $(<5 \%)$, sedangkan cara basah dilakukan pada ikan yang berkadar lemak tinggi ( $>5 \%)$. Perbedaan kedua cara ini terdapat pada proses pengukusan dan pengepresan pada cara basah yang tidak dilakukan pada cara kering. Sebagian besar proses pembuatan tepung ikan melalui tahap pemanasan, pengepresan, pengeringan dan penggilingan menggunakan mesin yang telah dirancang sebelumnya. Meski prosesnya sederhana, namun membutuhkan keterampilan dan pengalaman khusus untuk menghasilkan produk tepung ikan yang bermutu tinggi.

Penanganan limbah bagian kepala, isi perut, dan tulangnya yang dipisahkan dari produk utama (fillet daging sidat), dilakukan dengan cepat, hati-hati, suhu produk harus selalu dijaga tetap dingin $\left(5^{\circ} \mathrm{C}\right)$. Cara pengolahan dan proses pembuatan limbah ikan sidat menjadi tepung kepala, tepung tulang, dan tepung hati ikan melalui beberapa tahapan meliputi penyortiran, perebusan, pengepresan, pengeringan, penggilingan, pengemasan, dan pengepakan. Penyortiran dilakukan untuk memisahkan antara jenis bahan baku bagian kepala, tulang, dan hati ikan sidat yang baik karena pada proses produksi produk utama ikan sidat, limbah bagian kepala, isi perut dan tulang masih disatukan. Perebusan menggunakan autoklaf dengan suhu $121^{\circ} \mathrm{C}$ selama 2 jam untuk menghilangkan bakteri dan membuat tulang-tulang lunak, serta memudahkan proses selanjutnya (Mervina et al. 2012).

Pengepresan dilakukan untuk mengurangi kadar air dan memisahkan minyak ikan dari bahan baku yang telah mengalami proses perebusan serta untuk membuat masing-masing-masing bahan baku menjadi potongan-potongan yang lebih kecil sesuai dengan ukuran yang telah ditentukan. Proses ini berguna agar tepung yang dihasilkan menjadi lebih kering sehingga tahan lama. Pada tahap ini terjadi pemindahan sebagian minyak dan air. Ikan berada dalam tabung yang berlubang, hal tersebut dilakukan untuk meningkatkan tekanan dengan bantuan sekrup. Campuran air dan minyak yang diperoleh ditekan keluar melalui lubang dan bahan yang telah dipres membentuk padatan seperti dalam pembuatan kue. Dari hasil penelitian selama proses pengepresan, kadar air menurun dari 70\% menjadi $50 \%$ dan minyak menurun sekitar $4 \%$. Bahan yang berbentuk padatan yang telah dipres digiling dengan mesin penggiling daging, sehingga diperoleh bahan lebih halus.

Pengeringan dilakukan menggunakan drum dryer dengan suhu $80^{\circ} \mathrm{C}$ dan tekanan 3 bar untuk mengeringkan masing-masing bahan baku yang telah mengalami proses pengepresan. Meskipun caranya sederhana, akan tetapi membutuhkan keterampilan dalam melakukan proses pengeringan yang baik. Jika tepung tidak dikeringkan dengan baik maka dapat menyebabkan tumbuhnya jamur atau bakteri, sebaliknya jika pengeringan dilakukan secara berlebihan maka akan mengakibatkan nilai nutrisi yang dikandungnya dapat menurun. Penghalusan dilakukan dengan willey mill untuk menggiling bahan baku yang telah dikeringkan. Hasil dari proses 
Tabel 1. Hasil Analisis Kimia Ikan Sidat Segar, Kabayaki, dan Tepung Ikan Sidat

\begin{tabular}{lccccc}
\hline Parameter (\% w/w) & Tepung Kepala & Tepung Tulang & Tepung Hati & Ikan Sidat Segar & Kabayaki \\
\hline Kadar Air & 5.44 & 3.01 & 8.48 & 42.03 & 48.32 \\
Kadar Abu & 12.95 & 37.49 & 3.62 & 6.78 & 4.59 \\
Lemak & 15.55 & 13.07 & 27.28 & 48.80 & 4.62 \\
Protein & 61.78 & 41.01 & 53.92 & 30.50 & 63.27 \\
Karbohidrat & 11.48 & 8.13 & 14.96 & 16.44 & 26.49 \\
Serat Kasar & 1.33 & 1.11 & 0.04 & 0.52 & 1.06 \\
\hline
\end{tabular}

ini adalah tepung ikan yang sesuai dengan ukuran yang diinginkan.

Pengemasan dan pengepakan dilakukan dengan menggunakan aluminium foil dan dimasukkan ke dalam dus. Sebelum pengemasan, dipastikan kadar air tepung harus di bawah $10 \%$ sehingga tepung ikan dapat disimpan dalam jangka waktu yang lama (LIPI 1991). Tepung ikan yang sudah dikemas siap untuk didistribusikan atau selanjutnya dilakukan penyimpanan di dalam lemari pendingin atau gudang kering.

Sifat kimia tepung kepala, tulang, dan hati ikan sidat yang dianalisis diantaranya kadar air, abu, lemak, protein, karbohidrat, dan serat kasar. Adapun hasil analisis proksimat tepung ikan sidat disajikan dalam Tabel 1.

Tabel 1 menunjukkan bahwa persentase kandungan protein tepung kepala, tulang, dan hati lebih rendah dibandingkan dengan kabayaki, ikan sidat Indonesia segar dan juga ikan sidat Eropa segar (Anguilla anguilla) sebesar $17.68 \%$ (Özogul et al. 2005). Persentase kandungan protein ketiga jenis tepung tersebut cukup tinggi diduga karena proses pengepresan dan pengeringan dalam pengolahan tepung yang menyebabkan kadar airnya berkurang. Kandungan gizi terutama protein tepung kepala, tulang dan hati pada Tabel 1 menunjukkan bahwa limbah pengolahan ikan sidat memiliki nilai gizi yang tidak kalah dari produk utama kabayaki dan juga ikan sidat segar. Oleh sebab itu limbah pengolahan ikan sidat tersebut dapat dimanfaatkan sebagai bahan baku atau bahan tambahan pada diversifikasi produk makanan.

Tepung kepala ikan sidat memiliki kadar protein tertinggi dibandingkan dengan kadar protein tepung tulang dan hati ikan sidat serta tepung kepala ikan lele sebesar 56.04\% (Mervina et al. 2012). Kadar protein tepung tulang ikan sidat lebih tinggi dibandingkan dengan kadar protein tepung tulang ikan patin sebesar 17.41\% (Tababaka 2004), tepung tulang ikan madidihang sebesar $17.51 \%$ (Maulida 2005), tepung tulang ikan tuna sebesar 0.76\% (Trilaksani 2006) dan tepung tulang komersial produksi ISA sebesar $34.2 \%$. Tepung kepala, tulang dan hati ikan sidat tersebut tergolong makanan yang mengandung protein tinggi berdasarkan peraturan Kepala BPOM RI tahun 2011 (BPOM 2011).

Kadar air tepung tulang ikan sidat lebih rendah dibandingkan tepung kepala dan hati ikan sidat. Kadar air ketiga jenis tepung tersebut sesuai dengan LIPI (1991) dan BSN (2009) yang menyatakan bahwa tepung ikan yang berkualitas tinggi memiliki kadar air kurang dari $10 \%$. Tepung kepala ikan sidat memiliki kadar air lebih rendah dibandingkan tepung kepala ikan lele yaitu 8.72\% (Mervina 2012). Kadar air tepung tulang ikan sidat lebih rendah dibandingkan tepung tulang ikan patin sebesar 6.69\% (Tababaka 2004), tepung tulang ikan madidihang sebesar 3.76\% (Maulida 2005), tepung tulang ikan tuna sebesar 5.6\% (Trilaksani 2006) serta tepung tulang ikan komersial yang diproduksi oleh International Seafood of Alaska (ISA) 2002

Kadar abu dari yang tertinggi adalah tepung tulang selanjutnya tepung kepala dan tepung hati ikan sidat, hal ini sesuai dengan Moeljanto (1982) yang menyatakan bahwa sebagian besar abu dan mineral dalam tepung ikan berasal dari tulang ikan. Kadar abu tepung kepala ikan sidat lebih rendah dibandingkan dengan kadar abu basis kering tepung kepala ikan lele yaitu $14.10 \%$ (Mervina 2012). Tepung tulang ikan sidat memiliki kadar abu lebih rendah dibandingkan ikan tuna 81.13\% (Trilaksani 2006), ikan madidihang 67.94\% (Maulida 2005), dan ikan patin 63.12\% (Tababaka 2004), namun lebih tinggi dibandingkan dengan tepung tulang komersil produksi ISA sebesar 33.1\%.

Kadar lemak tepung hati ikan sidat lebih tinggi dibandingkan tepung kepala dan tulang ikan sidat. Tepung kepala ikan sidat memiliki kadar lemak lebih tinggi dibandingkan dengan ikan lele sebesar 9.93\% (Mervina et al. 2012). Begitu juga kadar lemak tepung tulang ikan sidat lebih tinggi dibandingkan ikan tuna sebesar 3.05\% (Trilaksani 2006), ikan patin sebesar 5.2\% (Tababaka 2004), tepung tulang ikan madidihang sebesar 6.26\% (Maulida 2005) dan tepung tulang komersial produksi ISA sebesar $5.6 \%$.

Tepung hati ikan sidat mengandung karbohidrat lebih tinggi dibandingkan dengan tepung kepala dan tulang ikan sidat, namun ketiga jenis tepung tersebut memenuhi syarat LIPI (1991) yang menya- 
takan bahwa tepung ikan kualitas baik maksimal mengandung 19\% karbohidrat. Kandungan karbohidrat tepung kepala ikan sidat lebih rendah dibandingkan dengan tepung kepala ikan lele sebesar $16.47 \%$ (Mervina et al. 2012). Tepung tulang ikan sidat memiliki kandungan karbohidrat lebih tinggi dibandingkan tepung tulang ikan patin sebesar 7.58\% (Tababaka 2004) dan lebih rendah dibandingkan tepung tulang komersial produksi ISA sebesar 23.5\%. Tepung kepala mengandung serat kasar sebesar 1.33\%, tepung tulang $1.11 \%$ dan tepung hati $0.04 \%$.

\section{KESIMPULAN}

Tepung ikan sidat adalah produk bergizi tinggi, kaya dengan protein dan mineral yang dapat digunakan sebagai bahan baku untuk diversifikasi pangan, bahan tambahan dan produk pangan fungsional. Hasil analisis proksimat menunjukkan bahwa tepung kepala, hati, dan tulang mengandung protein 61.78\%; 53.92\%; 41.01\%; lemak 15.55\%; 27.28\%; 13.07\%; karbohidrat 11.48\%; 14.96\%; 8.13\%, kadar air 5.44\%; 8.48\%; 3.01\%, kadar abu 12.95\%; 3.62\%; $37.49 \%$, serat kasar $1.33 \% ; 0.04 \% ; 1.11 \%$.

Pemanfaatan limbah ikan sidat menjadi tepung ikan diharapkan dapat mengoptimalkan kegiatan industri pengolahan perikanan sidat di $\mathrm{Pa}$ labuharatu, Sukabumi. Limbah industri pengolahan ikan sidat yang sebelumnya tidak termanfaatkan diharapkan dapat memiliki nilai ekonomi setelah diolah menjadi tepung ikan dan dapat mengurangi dampak pada lingkungan di unit pengolahan dan sekitarnya. Sebaiknya dilakukan penelitian lanjutan tentang pemanfaatan tepung ikan sidat sebagai makanan tambahan, diversifikasi pangan dan pangan fungsional, dan uji asam amino mengingat kadar protein tepung ikan sidat tinggi asam lemak, EPA, dan DHA, mineral seperti kalsium, fosfor, dan mineral penting lainnya.

\section{DAFTAR PUSTAKA}

[AOAC] Association of Official Analytical and Chemists. 1995. Official Methods of Analysis the 16th ed. Inc. Arlington, Virginia.

[BPOM RI] Badan Pengawasan Obat dan Makanan Republik Indonesia. 2011. Peraturan Kepala Badan Pengawasan Obat dan Makanan Republik Indonesia No. HK. 03.1.23.11.11.09909 Tahun 2011 tentang Pengawasan Klaim dalam Label dan Iklan Pangan Olahan. BPOM RI, Jakarta.

[BSN] Badan Standarisasi Nasional. 2009. Standar Nasional Indonesia (SNI) Tepung Ikan. Badan Standarisasi Nasional, Jakarta.

[KKP] Kementerian Kelautan dan Perikanan. 2011. Naskah Pidato Dirjen Budidaya, Kementerian
Kelautan dan Perikanan. Disampaikan dalam acara Seminar Minapolitan, 2011.

[LIPI] Lembaga Ilmu Pengetahuan Indonesia. 1991. Tepung ikan. Proyek sistem informasi nasional guna menunjang pembangunan, Jakarta.

Adeleke RO \& Odedeji JO. 2010. Acceptability studies on bread fortified with Tilapia fish flour. Pakistan Journal of Nutrition, 9(6), 531-534.

Altun T, Tekelioglu N, Nevsat E, \& Sagat Y. 2005. Some growth parameters on European eel (Anguilla Anguilla L, 1758) fed with different feeds. E.U Journal of Fisheries \& Aquatic Sciences, 22, 215-219.

Cameron GDT. 1960. Fish visceral flour as a source of protein for growing-finishing bacon pigs. Canadian Journal of Animal Science, 40(2).

Clusac IJ \& Ward AR. 1996. Post Harvest Fish Development: A Guide to Handling, Preservation, Processing and Quality. Natural Resources Institute, London.

[FAO] Food and Agriculture Organization. 2010. Fishery and Aquaculture Statistics, 2010 FAO yearbook annuaire anuarin, A-1 \& A-6.

Ferazuma H, Marliyati SA, \& Amalia L. 2011. Substitusi tepung kepala ikan lele dumbo (Clarias gariepinus) untuk meningkatkan kandungan kalsium crackers. Jurnal Gizi dan Pangan, 2011, 6(1), 18-27.

Gimenez AVG, Diaz AC, Velurtas SM, \& Fenucci JL. 2009. Partial substitution of fishmeal by meat and bone meal, soybean meal and squid concentrate in feeds for prawn, artemesia longinaris: effect on digestive proteinases. Israeli Journal of Aquaculture, 61 (1).

Green K. 2010. Annual review of the feed grade fish stocks used to produce fish meal and fish oil for the UK market. Industry environmental communications. Sea fish industry authority. Origin way Europarc, Grimsby.

Hadi M, Agustono, \& Cahyoko Y. 2009. Pemberian tepung limbah udang yang difermentasi dalam ransum pakan buatan terhadap laju pertumbuhan, rasio konversi pakan dan kelangsungan hidup benih ikan nila (Oreochromis niloticus). Jurnal Ilmiah Perikanan \& Kelautan, 1(2).

Harris H, Efreza D, \& Nafsiyah I. 2012. Potensi pengembangan industri tepung ikan dari limbah pengolahan makanan tradisional khas Palembang berbasis ikan. Jurnal Pembangunan Manusia, 6(3).

Haryati S, Sya'rani L, \& Agustini TW. 2006. Kajian substitusi tepung ikan kembung, rebon, rajungan dalam berbagai konsentrasi terhadap mutu fisika-kimia dan organoleptik pada mie instan. Jurnal Pasir Laut, (2)1, Juli 2006.

Heinsbroek LTN. 1991. A review of eel culture in Ja- 
pan and Europe. Aquaculture and Fishery Management, 22, 57-72.

Huber JT \& Slade LM. 1967. Fish flour as a protein source in calf milk replacer. Journal of Dairy Science, 50(8), 1296-1300.

Indarti S, Muhaemin M, \& Hudaidah S. 2012. Modified Toca Colour Finder (M-TCF) dan kromatofor sebagai penduga tingkat kecerahan warna ikan komet (Carasius auratus auratus) yang diberi pakan dengan proporsi tepung kepala udang (TKU) yang berbeda. e-Jurnal Rekayasa dan Teknologi Budidaya Perairan, 1(1) Oktober 2012.

Kureshy N, Davis DA, \& Arnold CR. 2000. Partial replacement of fish meal with meat-and-bone meal, flash-dried poultry by-product meal, and enzyme-digested poultry by product meal in practical diets for juvenile red drum. North American Journal of Aquaculture, 62, 266272.

Maulida N. 2005. Pemanfaatan tepung tulang ikan madidihang (Thunnus albacares) sebagai suplemen dalam pembuatan biskuit (crackers) [skripsi]. Fakultas Perikanan dan Ilmu Kelautan, Institut Pertanian Bogor, Bogor.

Mercy AD, Bindhu KB, \& Shyama K. 2006. Utilization of cuttle fish (Sepia officialis) bone meal as calcium supplement in the diet of pigs. The Indian Journal of Animal Sciences, (76)4.

Mervina, Kusharto CM, \& Marliyati SA. 2012. Formulasi biskuit dengan substitusi tepung ikan lele dumbo (Clarias gariepinus) dan isolat kedelai (Glycine max) sebagai makanan potensial untuk anak balita gizi kurang. J. Teknol. dan Industri Pangan, Vol XXIII (1).

Moeljanto.1982. Pengolahan Hasil-Hasil Samping Ikan. PT Penebar Swadaya, Jakarta.

Napitu R, Santoso L, \& Suparmono. 2013. Pengaruh penambahan Vitamin E pada pakan berbasis tepung ikan rucah terhadap kematangan gonad ikan nila merah (Oreochromis niloticus). e-Jurnal Rekayasa dan Teknologi Budidaya Perairan, Vol. I No.2 Februari 2013.

Özogul Y, Özyurt G, Özogul F, Kuley E, \& Rolat A. 2005. Freshness assessment of European eel (Anguilla anguilla) by sensory, chemical and microbiological methods. Food Chemistry, 92, 745-751.

Pretorius PJ \& Wehmeyer AS. 1964. An assessment of nutritive value of fish flour in the treatment of convalescent kwashiorkor patients. American Journal of Clinical Nutrition, Vol. 14, March 1964.
Salamah E \& Santoso J. 2008. Pemanfaatan tepung tulang ikan patin (Pangasius sp.) sebagai sumber kalsium dan fosfor dalam pembuatan biskuit. Ictyos VII(1), 9014.

Sari NP, Santoso L, \& Hudaidah S. 2012. Pengaruh penambahan tepung kepala udang dalam pakan terhadap pigmentasi ikan koi (Cyprinus carpio) jenis kohaku. e-Jurnal Rekayasa dan Teknologi Budidaya Perairan, I (1), Oktober 2012.

Selpiana, Santoso L, \& Putri B. 2013. Kajian tingkat kecernaan pakan buatan yang berbasis tepung ikan rucah pada ikan nila merah (Oreochromis niloticus). e-Jurnal Rekayasa dan Teknologi Budidaya Perairan, I(2), Februari 2013.

Shurpalekar SR, Daniel VA, Doraiswamy TR, Lahiry NL, Moorjani MN, \& Swaminathan. 1963. The effect of a supplementary protein food containing fish flour (from oil sardine) on the metabolism of nitrogen, calcium and phosphorus in children. The Indian Journal of Pediatrics, 30(8), 272-275.

Tababaka R. 2004. Pemanfaatan Tepung Tulang Ikan Patin (Pangasius Sp.) sebagai Bahan Tambahan Kerupuk [Skripsi]. Fakultas Perikanan dan Ilmu Kelautan, Institut Pertanian Bogor, Bogor.

Talib A, Santoso J, \& Ibrahim B. 2007. Pemanfaatan tepung tulang ikan madidihang sebagai sumber kalsium dan fosfor untuk meningkatkan nilai gizi Makron Kenari. Jurnal Sains Jurnal Ilmu-Ilmu Alam dan Terapan, 2(3), 5-2.

Traylor SL, Cromwell GL \& Lindemann MD. 2005. Bio-availability of phosphorus in meat and bone meal for swine. Journal of Animal Science, 83(5), 1054-1061, May 2005.

Trilaksani W, Salamah E, \& Nabil M. 2006. Pemanfaatan limbah tulang ikan tuna (Tunnus Sp.) sebagai sumber kalsium dengan metode hidrolisis protein. Jurnal Teknologi Hasil Pertanian. Vol IX Nomor 2 Tahun 2006.

Wu YV, Tudor KW, Brown PB, \& Rosati RR. 1999. Substitution of plant proteins or meat and bone meal for fish meal in diets of Nile Tilapia. North American Journal of Aquaculture, 61(1), 58-63, 1999/01.

Yolanda S, Santoso L, \& Harpeni E. 2013. Pengaruh substitusi tepung ikan dengan tepung ikan rucah terhadap pertumbuhan ikan nila gesit (Oreochromis niloticus). E-Jurnal Rekayasa dan Teknologi Budidaya Peraitan, I(2) Februari 2013. 